\title{
Extraction, purification and characterization of inhibitor of trypsin from Chenopodium quinoa seeds
}

\author{
Aline Regiele PESOTI ${ }^{1}$, Bruno Menezes de OLIVEIRA², Augusto Cesar de OLIVEIRA ${ }^{1}$, Dávia Guimarães POMPEU ${ }^{1}$, \\ Daniel Bonoto GONÇALVES ${ }^{1}$, Sérgio MARANGONI², José Antonio da SILVA ${ }^{1}$, Paulo Afonso GRANJEIRO ${ }^{1 *}$
}

\begin{abstract}
A novel trypsin inhibitor of protease (CqTI) was purified from Chenopodium quinoa seeds. The optimal extracting solvent was $0.1 \mathrm{M} \mathrm{NaCl} \mathrm{pH} 6.8(p<0.05)$. The extraction time of $5 \mathrm{~h}$ and $90{ }^{\circ} \mathrm{C}$ was optimum for the recovery of the trypsin inhibitor from $C$. quinoa seeds. The purification occurred in gel-filtration and reverse phase chromatography. CqTI presented active against commercial bovine trypsin and chymotrypsin and had a specific activity of 5,033.00 (TIU/mg), which was purified to 333.5-fold. The extent of purification was determined by SDS-PAGE. CqTI had an apparent molecular weight of approximately $12 \mathrm{KDa}$ and two bands in reduced conditions as determined by Tricine-SDS-PAGE. MALDI-TOF showed two peaks in $4,246.5$ and 7,908.18m/z. CqTI presented high levels of essential amino acids. N-terminal amino acid sequence of this protein did not show similarity to any known protease inhibitor. Its activity was stable over a $\mathrm{pH}$ range $(2-12)$, temperatures range $\left(20-100^{\circ} \mathrm{C}\right)$ and reducing agents.
\end{abstract}

Keywords: purification; characterization; inhibitor of trypsin; Chenopodium quinoa; seeds.

Practical Application: The purification and characterization of this novel trypsin inhibitor allow its study for a diversity of applications such as antibacterial, anticancer, anti-inflammatory and biotechnology and its further use as drugs for human diseases.

\section{Introduction}

Proteinase inhibitors (PIs) have important mechanism that plants produce to offer protection against predators or from infection by pathogens. They are widely distributed in the plant kingdom and the plant families Leguminoseae, Solanaceae and Graminaceae are known to be rich in these inhibitors (Nakahata et al., 2011). The PIs are small regulatory proteins generally present in high concentration and distributed in 10 families or more determined according to the primary structure, that is, the active amino acid in their reactive site, which are serine-, cysteine-, aspartic-, and metallo-PIs (Losso, 2008). In specially, plant serine-PIs are grouped into Bovine pancreatic trypsin inhibitor (Kunitz), Pancreatic secretory trypsin inhibitor (Kazal), Streptomyces subtilisin inhibitor, Soybean trypsin inhibitor (Kunitz), Soybean proteinase inhibitor (Bowman-Birk), Potato I inhibitor, Potato II inhibitor, Ascaris trypsin inhibitor and Other families (Laskowski \& Kato, 1980).

The most popular classes of PIs are Kunitz and BBI (Bowman-Birk). The Kunitz inhibitors family is usually $18-24 \mathrm{kDa}$ heterogeneous proteins consisting of a number of isoinhibitors, with two disulfide linkages and a single trypsin reactive site (defined by an arginine residue) in one of the protein loops. The BBI are small cysteine-rich proteins in size $(8-20 \mathrm{kDa})$, with seven disulfide linkages, high cysteine content, and two independent reactive sites for trypsin and chymotrypsin, soluble between $\mathrm{pH} 1.5$ and 12 and in dry state or in $0.02 \%$ aqueous solution is stable at $100^{\circ} \mathrm{C}$ or at $105^{\circ} \mathrm{C}$ for $10 \mathrm{~min}$, respectively (Losso, 2008). These classes of proteins has been studied due to its application in the treatment of different pathologies as cancer (Zhang et al., 2011), antifungal activity (Kim et al., 2005), inflammation and coagulation (Machado et al., 2013) or as bioinsecticides (Rai et al., 2010), demonstrating its importance as new therapeutic agents for the pharmaceutical industry. Despite there are abundantly studies of PIs in leguminous plants, little is known in cereals, such as amaranth (Tamir et al., 1996); buckwheat (Park et al., 1997) and buckwheat Seeds (Tsybina et al., 2001).

The Chenopodium quinoa, a pseudo-cereal, is original cultivated in Colombia, Peru, Bolivia, Equator, Chile and Argentina in variety latitudes and altitudes. Due to its potential food source and South America limited production, C. quinoa has being introduced in Europe, North America, Africa and Asia (Bhargava et al., 2006). This has contributed for its popularization, especially in the developing countries, as alternative food, which had to its high nutritional importance. Quinoa has high concentration of essential aminoacids and high content of calcium, magnesium, iron, copperand and zinc, and are rich in vitamins, as $\alpha$-carotene and niacin (Vega-Gálvez et al., 2010). Especially, chemical composition revealed the potential of $C$. quinoa seeds as a valuable ingredient in the preparation of cereal foods of improved nutritional characteristics (Stikic et al., 2012), but heat is necessary to degradation of antinutritional factors for 
human consumption (Silva et al., 2015a). In Brazil, the C. quinoa was introduced in the decade of 1990, as part of an effort to diversification of production systems in the cerrado (Savannah), the Brazilian hotspot (Spehar \& Santos, 2002). The purpose of this work was extraction, purification and characterization of the protease inhibitors isolated from Chenopodium quinoa seeds.

\section{Materials and methods}

\subsection{Chemicals}

BSA (bovine serum albumin), bovine pancreatic trypsin, bovine pancreatic a-chymotrypsin, papain, a-amylase, casein, BTpNA (N-Benzoyl-L-tyrosine p-nitroanilide) and BApNA (N-R-benzoyl-DL-arginine-p-nitroanilide) were purchased from Sigma (St. Louis, MO, USA), as were molecular weight markers standard, acrylamide, bis-acrylamide, DTT (Dithiothreitol) and other electrophoresis reagents. TNBS (2,4,6-trinitrobenzenesulfonic acid), TFA (Trifluoroacetic acid) were purchased from Merck (Darmstadt, Germany). The chromatography supports were from GE Healthcare Life Sciences (Uppsala, Sweden). All other chemicals and reagents used were of analytical grade.

\subsection{Preparation of seed flour}

The C. quinoa seeds were courtesy from Carlos Roberto Spehar, researcher at University of Brasília. The seeds were washed and crushed using a blender to obtain flour. The seeds $(50 \mathrm{~g})$ were ground in an electric mill and the seed flour obtained it was used in the next step.

\subsection{Effect of extraction media on trypsin inhibitor extraction}

Different extracting solvent including distilled water, $0.1 \mathrm{M}$ $\mathrm{NaCl}, 0.15 \mathrm{M} \mathrm{NaCl}, 0.30 \mathrm{M} \mathrm{NaCl}, 0.01 \mathrm{M} \mathrm{NaOH}$ and $0.02 \mathrm{M} \mathrm{NaOH}$ were used to extract protease inhibitor according Klomklao et al. (2011). The seed flour was added to the medium at a ratio of solvent mass to feed mass of 5:1 (S/F) and shaken for $1 \mathrm{~h}$ at $150 \mathrm{rpm}$ at room temperature. The extract was recovered by centrifuging at $10,000 \mathrm{~g}$ for $30 \mathrm{~min}$. The trypsin inhibitory activity and protein content in the supernatant were determined and the specific inhibitory activity obtained using different media were compared. The extracting solvent used for solubilizing the trypsin inhibitor, which was able to extract the trypsin inhibitor with the highest specific trypsin inhibitory activity, was selected for further steps.

\subsection{Effect of extraction time on trypsin inhibitor extraction}

Seed flour was mixed with $0.1 \mathrm{M} \mathrm{NaCl}$ in a ratio of 5:1 (S/F) and, then, shaken for 1, 2, 3, 4, and $5 \mathrm{~h}$. At designated time, the mixture was centrifuged at $10,000 \mathrm{~g}$ for $30 \mathrm{~min}$ and the supernatants were subjected to the determination of the trypsin inhibitory activity and protein content. The specific trypsin inhibitory activities were then calculated. The extracting time rendering the highest specific trypsin inhibitory activity was chosen for further study.

\subsection{Effect of extraction temperature on trypsin inhibitor extraction}

Seed flour extract in $0.1 \mathrm{M} \mathrm{NaCl}$ and shaken for $5 \mathrm{~h}$ was heated at different temperatures (room, 37, 60, 70, 80, 90 and $100{ }^{\circ} \mathrm{C}$ ) for $10 \mathrm{~min}$ and then cooled with ice water. To remove the heat coagulated debris, the extracts were centrifuged at $10,000 \mathrm{~g}$ for 10 min at $4{ }^{\circ} \mathrm{C}$. The activity and specific activity of the trypsin inhibitor in the supernatant was measured. The heat treatment, which gave the supernatant with the highest specific activity, was chosen for further study.

\subsection{Purification of trypsin inhibitor from Chenopodium quinoa seeds}

The heat-treated extract was subsequently submitted at different ammonium sulfate precipitation (0-40\% and $40-90 \%$ saturation) and the protein content and trypsin inhibitory activity was analysed. The highest specific activity of the fractions was selected and lyophilized.

The lyophilized was dissolved in AMBIC (Ammonium bicarbonate) buffer $1 \mathrm{M}$ and applied to an exclusion molecular Sephadex G-50 $(1.0 \times 50 \mathrm{~cm}$, eluted with AMBIC buffer $0.2 \mathrm{M})$ equilibrated with the same buffer, with a flow rate of $0.5 \mathrm{~mL} / \mathrm{min}$. The single peak of antitryptic activity was collected and dialyzed against distilled water and lyophilized. The G-50 column fraction was then separated by reverse-phase HPLC, as described by Macedo et al. (2007), on a Hypersil Gold C18 $(300 \times 4 \mathrm{~mm})$ (Thermo Scientific) that was previously equilibrated with $0.1 \%$ (v/v) TFA (solvent A), followed by a 50 min linear gradient from 0 to $100 \%(\mathrm{v} / \mathrm{v})$ of $66 \%(\mathrm{v} / \mathrm{v})$ acetonitrile in $0.1 \%(\mathrm{v} / \mathrm{v})$ TFA (solvent B) with a flow rate of $0.5 \mathrm{~mL} / \mathrm{min}$. Proteins were detected by monitoring absorbance at $280 \mathrm{~nm}$.

\subsection{Determination of protease inhibitory activity}

The inhibitory activity against proteinases was determined by measuring the remaining hydrolytic activity toward specific synthetic substrates after pre-incubation with CqTI (Silva et al., 2015a). The inhibitory activity against chymotrypsin and trypsin was determined toward the substrate BTpNA and BApNA, respectively, in Tris (2-Amino-2-hydroxymethyl-propane-1,3-diol) buffer $\mathrm{pH} 8.0$ at $37^{\circ} \mathrm{C}$ in $30 \mathrm{~min}$. The reaction was stopped with $500 \mu \mathrm{L}$ acetic acid 30\% (v/v), and the substrate hydrolysis followed by absorbance at $405 \mathrm{~nm}$. All assays were done in triplicate. One trypsin unit (TU) was arbitrarily defined as an increase of 0.01 absorbance units at $405 \mathrm{~nm}$ per ml of reaction medium. Results were expressed as units of trypsin inhibitory (TI) per $\mathrm{mg}$ protein, one inhibitory unit responsible for the inhibition of one unit of trypsin.

\subsection{Protein determination}

Protein contents were determined using Coomassie blue staining by Bradford method (Bradford, 1976) or by absorbance at $280 \mathrm{~nm}$. BSA $(1 \mathrm{mg} / \mathrm{ml})$ was used a standard. 


\subsection{Tricine Sodium Dodecyl Sulfate Polyacrylamide Gel (SDS-PAGE)}

Tricine SDS-PAGE was carried out according to the procedure of Schägger \& von Jagow (1987) with some modifications. The separating gel, spacer gel, and stacking gel were well prepared and solidified. For supernatant, the highest protein concentration sample was diluted to $1 \mathrm{mg} / \mathrm{mL}$. Precipitate samples were treated with the same method as supernatant. Then $0.5 \mathrm{~mL}$ of diluted sample was mixed with $0.5 \mathrm{~mL}$ of sample buffer $[0.05 \mathrm{M}$ Tris- $\mathrm{HCl}$ at $\mathrm{pH}$ $6.8,4 \%(\mathrm{w} / \mathrm{v})$ SDS, $12 \%(\mathrm{v} / \mathrm{v})$ glycerol, $0.01 \%(\mathrm{w} / \mathrm{v})$ bromophenol blue, and 2\% (v/v) 2-ME (or no for nonreducing)] effectively and heated for $3 \mathrm{~min}$ in a boiling water bath, then centrifuged at $10000 \mathrm{rpm}$ for $3 \mathrm{~min}$. Then $10 \mu \mathrm{L}$ or $20 \mu \mathrm{L}$ of each sample was loaded into a well. Tricine SDS-PAGE was performed at $30 \mathrm{~V}$ for $1 \mathrm{~h}$, and then up to $100 \mathrm{~V}$. After electrophoresis, the gels were stationed for $2 \mathrm{~h}$ in stationary liquid [ $45.4 \%$ (v/v) methanol, $9.2 \%(\mathrm{v} / \mathrm{v})$ glacial acetic acid] and then stained for $2 \mathrm{~h}$ using $0.1 \%(\mathrm{w} / \mathrm{v}$ ) Coomassie Brilliant Blue R-250. After staining, the gels were distained using a $10 \%(\mathrm{v} / \mathrm{v})$ acetic acid solution until a clear background was obtained. The proteins used as molecular weight standards for Sodium Dodecyl Sulfate Polyacrylamide Gel Electrophoresis (SDS-PAGE) were phosphorylase b (94kDa), bovine serum albumin $(66 \mathrm{kDa})$, ovalbumin $(44 \mathrm{kDa})$, bovine anhydrase carbonic $(30 \mathrm{kDa})$, inhibitor of trypsin $(20 \mathrm{kDa})$, lysozyme (14.kDa).

\subsection{Mass spectrometry analysis}

Samples were mixed with a-cyan matrix (CHCA) in the ratio of $1: 1$ and aliquots of $1 \mu \mathrm{L}$ were applied in the reading plate of the mass spectrometer Voyager TM Biopectrometry (Applied Biosystems). Operating in reflector positive mode, the detection of ions was achieved by the associated mass espectrometric techniques matrix-assisted laser desorption/ionization and time-of-flight (MALDI/TOF MS). Calibration was done externally with a mixture of four standard proteins with their respective mass/charge ratio.

\subsection{Amino acid analysis}

Amino acid analysis was performed in a Pico-Tag amino acid analyzer (Water System), as described by Heinrikson \& Meredith (1984). One nmol of CqTI was hydrolyzed in $6 \mathrm{M}$ $\mathrm{HCl}$ and $1 \%$ phenol at $106^{\circ} \mathrm{C}$ for $24 \mathrm{~h}$. The hydrolysates were reacted with $20 \mathrm{ml}$ of fresh derivatization solution methanol/ triethylamine/water/phenylisothio-cyanate, $7: 1: 1: 1,(\mathrm{v} / \mathrm{v})$ for $1 \mathrm{~h}$ at room temperature. After pre-column derivatization, phenylthiocarbamyl-amino acids were identified by comparing their reverse phase high-performance liquid chromatogray (HPLC) retention times to those of standard PTC-amino acids (Pierce). Cysteine residues were quantified as cysteic acid.

\section{$2.13 N$-terminal sequence determination}

Initially the native inhibitor was reduced and modified with 4-vinylpyridine and two chains were separated by HPLC. The sequence of first 13 and 10 amino acids each subunits from N-terminal end of CqTI was determined by Edman degradation method (Edman et al., 1950) using an 477A - Applied Biosystems. 500pmoles purified CqTI was electrophoresed on SDS-PAGE (15-4\%) and was electrophoretically transferred to a polyvinyl difluoride (PVDF) membrane (Mini Trans-Bolt Electrophoretic Transfer Cell, Bio Rad). The membrane was stained with CBB R-250, destained and washed thoroughly to remove any bound glycine to the membrane. The lanes of CqTI band on the membrane was cut and loaded on to the protein sequencer. Percent homology of N-terminal amino acid sequence of CqTI with other known sequences of proteins was assessed using protein sequence database, SWISS-PROT by all the relevant BLAST programs, i.e. NCBI-protein-protein blast (blastp), NCBI-blast- search for short nearly exact matches, and NCBI-protein query vs. translated database (tblastn). Further the search was done in protein sequence database, UNIPROT using the BLAST program WU-blastp and WU-tblastn.

\subsection{Stability studies}

In stability studies, effect of $\mathrm{pH}$, temperature and DTT was examined on inhibitory activity of CqTI against trypsin. In $\mathrm{pH}$ stability, trypsin inhibition assays under a range of $\mathrm{pH}(2-12)$ conditions were performed to assess the $\mathrm{pH}$ stability and $\mathrm{pH}$ optima of CqTI. Purified CqTI ( $50 \mu \mathrm{g})$ was incubated with buffers of $\mathrm{pH} 2,3,4,5,6,7,8,9,10,11$ and 12 to a final con- centration of $1 \mathrm{mg} / \mathrm{ml}$. The buffers used were $0.1 \mathrm{M}$ each of glycine- $\mathrm{HCl}$ buffers ( $\mathrm{pH} 2,3)$, acetate buffers ( $\mathrm{pH} 4,5)$, phosphate buffers (pH 6, 7), Tris-HCl buffers ( $\mathrm{pH} 8,9$ ) and glycine-NaOH buffers ( $\mathrm{pH} 10,11,12$ ). After incubation of $30 \mathrm{~min}$, the trypsin inhibitory activity was determined at $\mathrm{pH}$ 8.0. In thermal stability studies, purified protein $(50 \mu \mathrm{g})$ in $50 \mathrm{mM}$ Tris- $\mathrm{HCl}$ buffer $\mathrm{pH} 8.0$ was incubated at various temperatures $\left(20-100^{\circ} \mathrm{C}\right)$ for $30 \mathrm{~min}$. After incubation, all the samples were kept on ice for $15 \mathrm{~min}$ and then centrifuged. Supernatants were taken for the estimation of residual trypsin inhibitory activity and measured using BAPNA as substrate at $37^{\circ} \mathrm{C}$. The effect of DTT on inhibitory activity was determined by incubating purified CqTI $(50 \mu \mathrm{g})$ with DTT at final concentrations of 1,10 and $100 \mu \mathrm{M}$ for $15,30,60$ and $120 \mathrm{~min}$ at $37^{\circ} \mathrm{C}$. Adding twice the amount of iodoacetamide to each DTT concentration stopped the reaction and then the residual trypsin inhibitory activity was measured. All experiments were done in triplicate and the results are the mean of three assays.

\subsection{Statistic analyses}

Mean pairwise comparisons residual activity of trypsin and chymotrypsin was carried out by setting a General Linear Model ANOVA ( $\alpha=0.05)$, followed by Tukey Method and 95\% Confidence.

\section{Results and discussion}

\subsection{Extraction of trypsin inhibitor from C. quinoa seeds}

We used various extracting solvent to extract the trypsin inhibitor from Chenopodium quinoa seeds (Table 1). The better extractant was $\mathrm{NaCl} 0.1 \mathrm{M}(p<0.05)$ with $26.07( \pm 0.019)$ and $12.18( \pm 0.0094)$ as highest trypsin inhibitor activity and specific trypsin inhibitor, respectively. From the results, $\mathrm{NaCl}$ 
$0.1 \mathrm{M}$ was chosen as the extraction medium for $C$. quinoa seed trypsin inhibitor.

The effect of extraction time was investigated on the recovery of trypsin inhibitor from C. quinoa seeds. Higher extraction efficiency was found when the extraction time increased up to $5 \mathrm{~h}(p<0.05)$ for inhibitory activity and specific inhibitory activity (Figure 1a, b). In the literature the extraction time varies from 30min to 3h (Benjakul et al., 2000; Klomklao et al., 2010a; Klomklao et al., 2010b; Klomklao, 2011). Therefore, the extraction time of $5 \mathrm{~h}$ was selected for the extraction of trypsin inhibitor from C. quinoa seeds.

At different temperatures the heat treatment of the C. quinoa extract was carried out. The trypsin inhibitory activity markedly increased after heat treatment at $60{ }^{\circ} \mathrm{C}$, whilst the inhibitor activities of the C. quinoa extract were quite constant up to $90^{\circ} \mathrm{C}$ and maintained at $100{ }^{\circ} \mathrm{C}$ (Figure 1c). For the specific trypsin inhibitory activity, it was increased markedly when the heating temperature increased up to $90^{\circ} \mathrm{C}$ (Figure 1d). The temperature of $90^{\circ} \mathrm{C}$ was chosen for C. quinoa seed trypsin inhibitor. Heating the plant extract promoted thermal coagulation of the aggregate contaminants protein and increased specific inhibitory of protease (Benjakul et al., 2000). In our study, the use of heat treatment during the extracting time contributed for the less necessity of chromatograph steps.

The heat-treated extract was subsequently submitted at different range of ammonium sulfate precipitation. According to specific inhibitory activity the ammonium sulfate saturation $0-40 \%$ and $40-90 \%$ at room temperature and heated at $90{ }^{\circ} \mathrm{C}$ showed lower efficiency when compared with extratcion without ammonium sulfate preciptation (not shown). The use of heat treatment without ammonium sulfate precipitation was observed for AmI from Amaranth seeds (Tamir et al., 1996) and represents an important step to simplify the purification.

\subsection{Purification of trypsin inhibitor from C. quinoa}

Inhibitor of protease from C. quinoa seeds was isolated through a two-step purification process. The behavior of the soluble protein fraction submitted to a size-exclusion chromatography on a Superdex G-50 was demonstrated (Figure 2a). The proteins eluted into four peaks, which only peak II showed TI activity, were pooled and further applied onto a reverse phase HPLC.

In the second step, protein with trypsin inhibitory activity was chromatographed on reverse phase HPLC where it showed four peaks (Figure $2 \mathrm{~b}$ ). The peak C (CqTI) showed activity for chymotrypsin and trypsin while peak $\mathrm{A}$ was inactive for both enzymes. The peaks B and D presented only chymotrypsin activity.

The identification of chymotrypsin inhibitory activities for the three fractions eluted from RP-HPLC suggests the presence of $\mathrm{PI}$ isoforms in C. quinoa seeds. The literature has demonstrated the existence of numerous isoinhibitors in plants such as in Cajanus cajan (Prasad et al., 2009), Vigna unguiculata (Rao \& Suresh, 2007) and Fagopyrum tataricum seeds (Ruan et al., 2011). The nature of a large number of isoforms could be explained by the existence of multiple genes and the possibility of hydrolysis (Kalume et al., 1995). New forms of PIs and proteinases had been developed in plants and insects to combat against each other's in coevolution system (Harsulkar et al., 1999).

The specific activity in the initial enzyme extract was $15.09 \mathrm{TIU} / \mathrm{mg}$, whilst total activity was 804.28 . The first step (Sephadex G-50) resulted in a strongly increase in the specific activity, generating a purification factor of 268-fold and a yield of $73.2 \%$. In the second step (reverse phase HPLC), the degree of purification was 333.5-fold higher than the enzyme extract with specific activity and yielding of 5,033 and $42.8 \%$, respectively (Table 2 ). These results were better that observed in the literature (Cheung et al., 2009; Prasad et al., 2010a, b; Klomklao et al., 2011).

\subsection{Tricine SDS-PAGE}

Tricine SDS-PAGE under reducing and non-reducing conditions analyze the purity of the protein in fractions eluted from reverse phase HPLC (Figure 2c). The analysis showed that the isoform $\mathrm{C}$, in non-reduction conditions, presented one band with a molecular mass of approximately $12 \mathrm{kDa}$. However, in reduction conditions, showed a double polypeptide chain with a molecular mass of approximately 4 and $8 \mathrm{KDa}$. Other studies showed heterodimers PIs on SDS-PAGE denaturing conditions (Macedo et al., 2011; Klomklao et al., 2011).

\subsection{Mass spectrometry}

The profile of CqTI mass spectrometry (Figure 3), which showed two predominant signals peaks at 4246.5 and $7908.18 \mathrm{~m} / \mathrm{z}$, reinforce the hypothesis that the inhibitor of quinoa is composed of two heterogeneous subunits, corresponding to the masses of 4.2 and $7.9 \mathrm{KDa}$, respectively. These results confirm the data obtained from Tricine SDS-PAGE.

Table 1. Effect of extractants on the recovery of trypsin inhibitor from C. quinoa seeds. Mean \pm SD from triplicate determinations.

\begin{tabular}{|c|c|c|c|}
\hline Extracting Solvent* & Total IU & Total Protein (mg) & $\begin{array}{c}\text { Specific Inhibitory Activity } \\
\text { (Units/mg of protein) }\end{array}$ \\
\hline Water & $14.68 \pm 0.050^{\mathrm{a}}$ & $2.73 \pm 0.031^{\mathrm{a}}$ & $5.38 \pm 0.012^{\mathrm{a}}$ \\
\hline $\mathrm{NaCl} 0.1 \mathrm{M}$ & $26.07 \pm 0.019^{b}$ & $2.14 \pm 0.020^{\mathrm{b}}$ & $12.18 \pm 0.0094^{\mathrm{b}}$ \\
\hline $\mathrm{NaCl} 0.15 \mathrm{M}$ & $23.43 \pm 0.013^{\mathrm{c}}$ & $1.93 \pm 0.034^{\mathrm{c}, \mathrm{b}}$ & $12.14 \pm 0.018^{\mathrm{b}, \mathrm{c}}$ \\
\hline $\mathrm{NaCl} 0.3 \mathrm{M}$ & $23.46 \pm 0.053^{c}$ & $2.19 \pm 0.012^{\mathrm{d}, \mathrm{b}}$ & $10.71 \pm 0.0059^{\mathrm{d}}$ \\
\hline $\mathrm{NaOH} 0.02 \mathrm{M}$ & $26.10 \pm 0.005^{\mathrm{b}}$ & $3.05 \pm 0.027^{\mathrm{e}}$ & $8.56 \pm 0.0089^{\mathrm{e}}$ \\
\hline $\mathrm{NaOH} 0.01 \mathrm{M}$ & $25.90 \pm 0.026^{\mathrm{b}}$ & $3.29 \pm 0.014^{\mathrm{f}}$ & $7.87 \pm 0.0044^{\mathrm{f}}$ \\
\hline
\end{tabular}

The different latters in the same column denote the significant differences (ANOVA, $\mathrm{p}<0.05$ ). ${ }^{\star}$ The seed flour was shaken en different media at ambient temperature for $1 \mathrm{~h}$ and trypsin inhibitor was analyzed using BAPNA as substrate. 

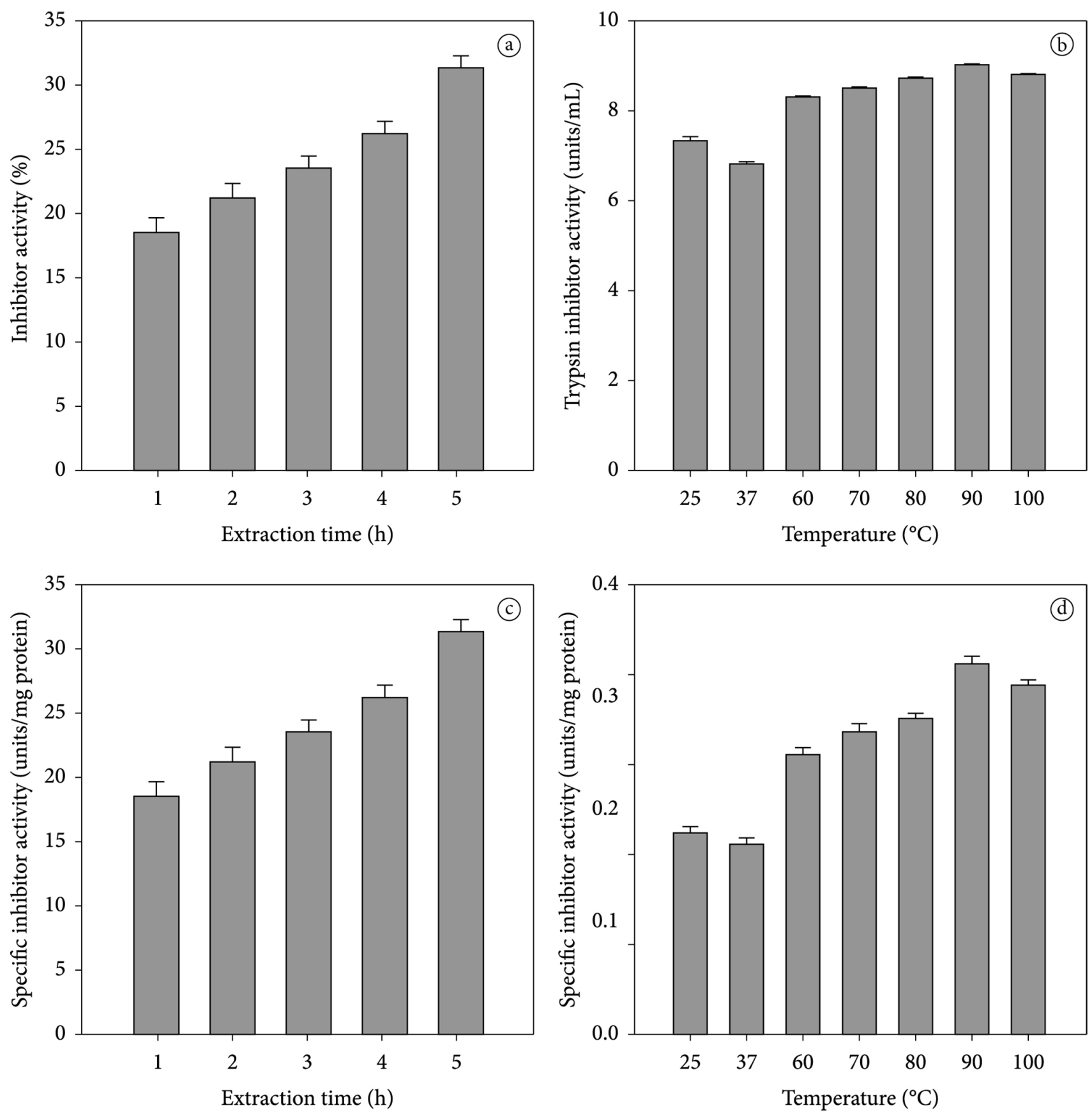

Figure 1. Effect of extraction time on the specific trypsin inhibitory activity (a) and trypsin inhibitory activity (b) of C. quinoa seed extract. Effect of heat treatment at different temperatures on the trypsin inhibitory activity (c), and specific trypsin inhibitory activity (d) of C. quinoa seed extract. There was a significant difference between the times evaluated (ANOVA, $\mathrm{p}<0.05$ ).

\subsection{Amino acid composition}

The study of the amino acid composition demonstrated a high concentration of essential amino acids, lysine and valine (R aliphatic nonpolar group) in CqTI (Table 3). The quantity of histidine, lysine and leucine demonstrated better similarity with legumes species (Silva et al., 2001; Machado et al., 2013). The concentration of Glu, Gli and Arg was better than the concentration in cereal and legume (Tamir et al., 1996; Silva et al., 2001). The presence of four cysteine residues was similarly that observer for the trypsin inhibitor (BWI-2c) from buckwheat (Fagopyrum esculentum) (Tsybina et al., 2001). This pool of amino acids of quinoa was found close to the standards of the FAO/WHO for high-quality protein (Ruales \& Nair, 1992).

\subsection{N-terminal amino acid sequence}

The amino acid sequencing of each subunit revealed that CqTI has two different sequences AFQNTGKQAWNTG and AREDPYTWSW, which were not homologous to any other 

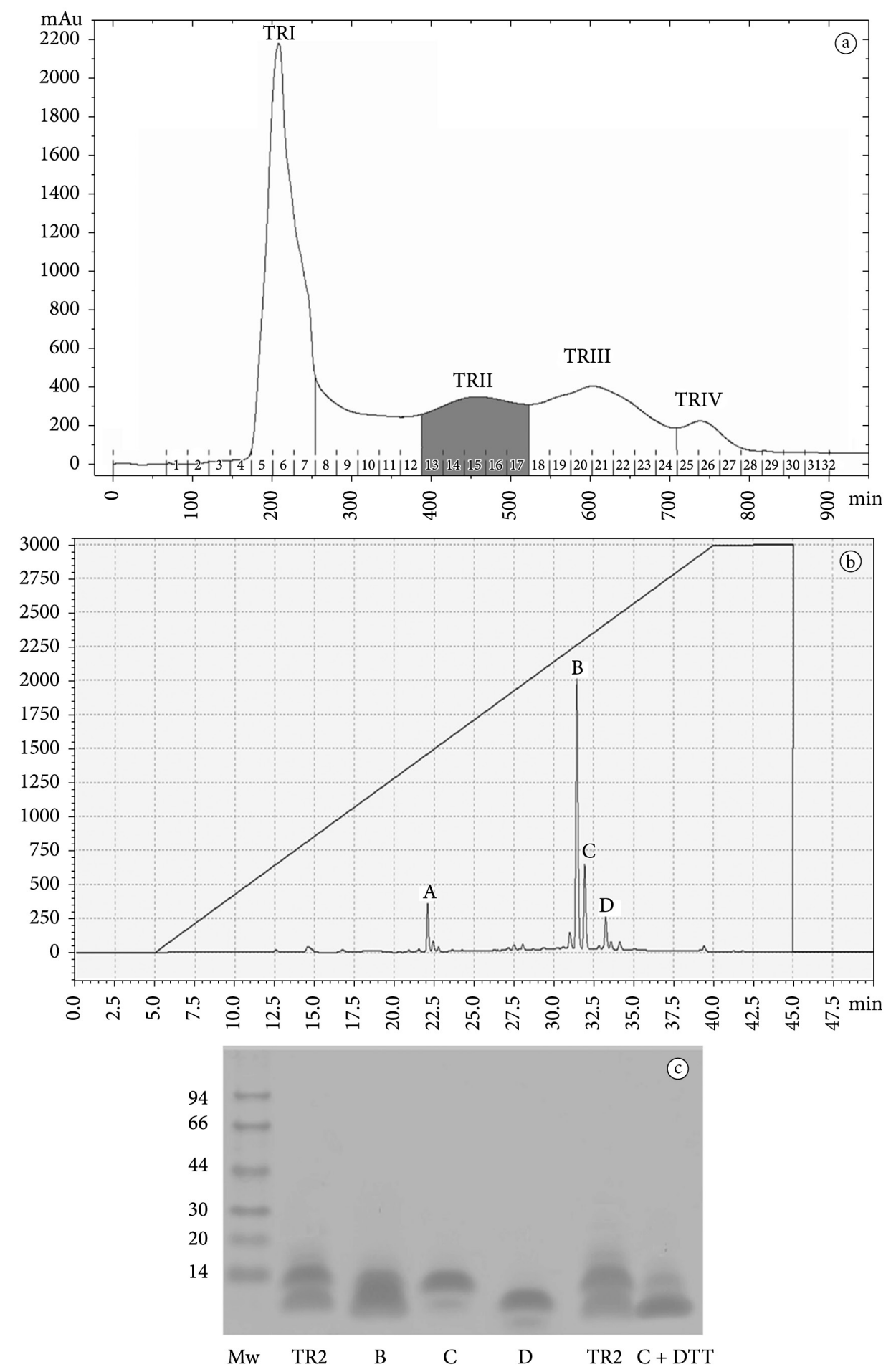

Figure 2. (a) Gel filtration of the CqTi on Superdex G-50 on FPLC system. (b) Elution profiles for RP-HPLC analysis of C. quinua trypsin inhibitor (CqTi). (c) Sodium dodecyl sulphate polyacrylamide gel electrophoresis of proteinase inhibitor from C. quinoa seed and different fractions under reducing and nonreducing condition. MW: moleular weight standard; TR2: Sephadex G-50 fraction; B: B fraction from RP-HPLC, C: C fraction from RP-HPLC, D: D fraction from RP-HPLC, C + DTT: C fraction from RP-HPLC + DTT.

Table 2. Purification of trypsin inhibitors from C. quinoa seeds.

\begin{tabular}{ccccccc}
\hline Purification step & Mg prot/g seed & TUI/g seed & TUI/mg prot & Purification fold & Protein Yield (\%) & Activity Yield (\%) \\
\hline Crude extract & 53.291 & 804.28 & 15.09 & 1 & 100 & 100 \\
Sephadex G50 & 0.145 & 588.14 & 4.056 & 268 & 0.27 & 73.2 \\
C18 & 0.0684 & 344.27 & 5.033 & 333.5 & 0.13 & 42.8 \\
\hline
\end{tabular}




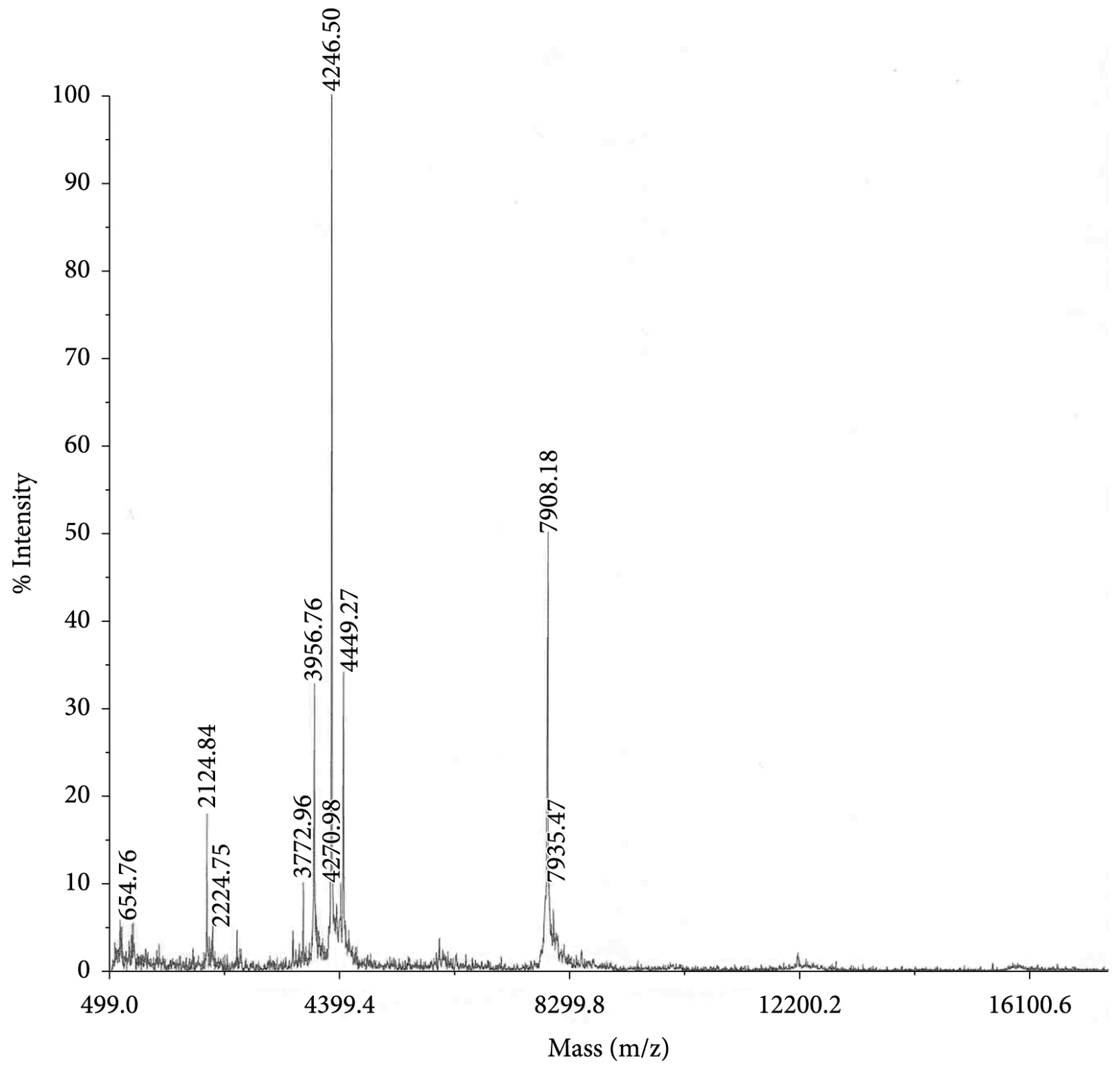

Figure 3. Mass spectrophotometric profile of CqTI showing peaks corresponding to the charged ions $[\mathrm{M}+\mathrm{H}]+$ and $[\mathrm{M}+2 \mathrm{H}+/ 2]$ with its respective mass/charge ratio (analyzed on MALDI-TOF). The principal peaks correspondent for 4.2 and $7.9 \mathrm{kDa}$ molecular masses.

Table 3. Amino acid composition of CqTI from C. quinoa in comparison with Bowman-Birk LSI-1 (Rocco et al., 2011) and TDI-I Kunitz (Silva et al., 2001).

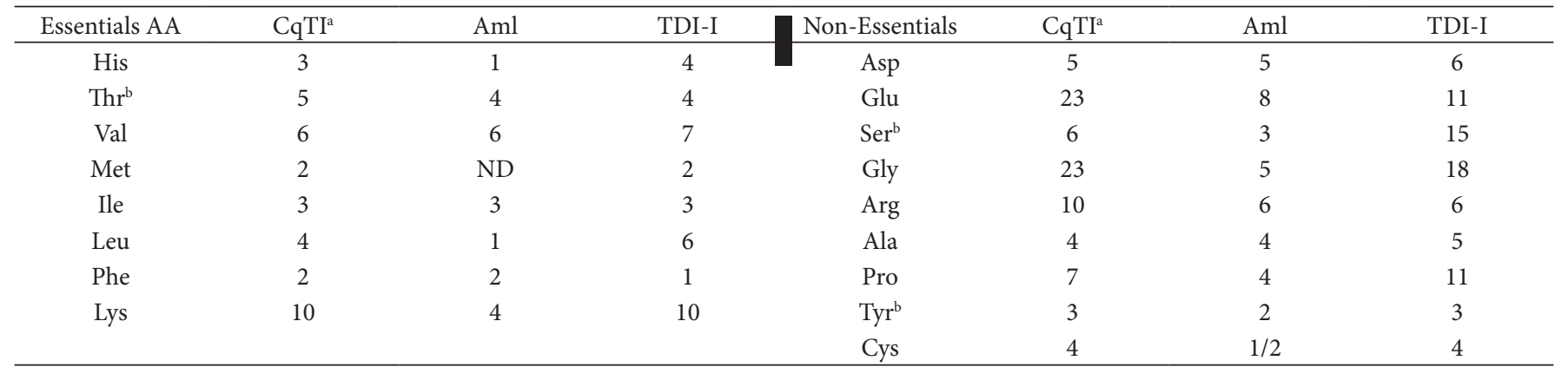

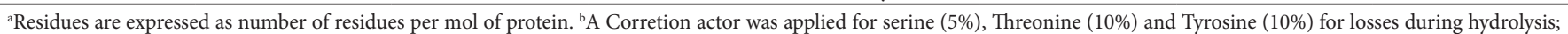
nd, not determined. 
known sequence of inhibitor of trypsin and chymotrypsin, which makes it a unique protein. No similarity in N-terminal sequences with other classes of inhibitor of protease were observed (Park et al., 1997; Tsybina et al., 2001).

\subsection{Inhibition curve, $p H$, Temperature and DTT Stability}

CqTI showed trypsin and chymotrypsin activities (Figure 4a), however the inhibitory activity was higher against trypsin than chymotrypsin. Trypsin lost $65 \%$ of its activity when the molar ratio of CqTI to trypsin was 0.75 and further lost $75 \%$ of its activity when the molar ratio was increased to 1.0. In contrast, CqTI showed no obvious stoichiometry with chymotrypsin. The study of the effects of $\mathrm{pH}(2-10)$ and temperature $\left(20-100^{\circ} \mathrm{C}\right)$ revealed the high stability of the inhibitor against trypsin. In $\mathrm{pH}$ stability studies, CqTI was highly stable under conditions in the $\mathrm{pH}$ range 2-10 for $1 \mathrm{~h}$ (Figure $4 \mathrm{~b}$ ). The inhibitory activity of CqTI was maintained at temperatures of up to $40^{\circ} \mathrm{C}$ for $30 \mathrm{~min}$. Above $40{ }^{\circ} \mathrm{C}$, the inhibitory activity decreased slightly, but maintained $70 \%$ activity at up to $100^{\circ} \mathrm{C}$ for $30 \mathrm{~min}$ (Figure $4 \mathrm{c}$ ). The effect of DTT $(1,10$ and $100 \mu \mathrm{M})$ on CqTI activity was studied (Figure $4 \mathrm{~d}$ ). When CqTI was incubated with $1 \mu \mathrm{M}$ of

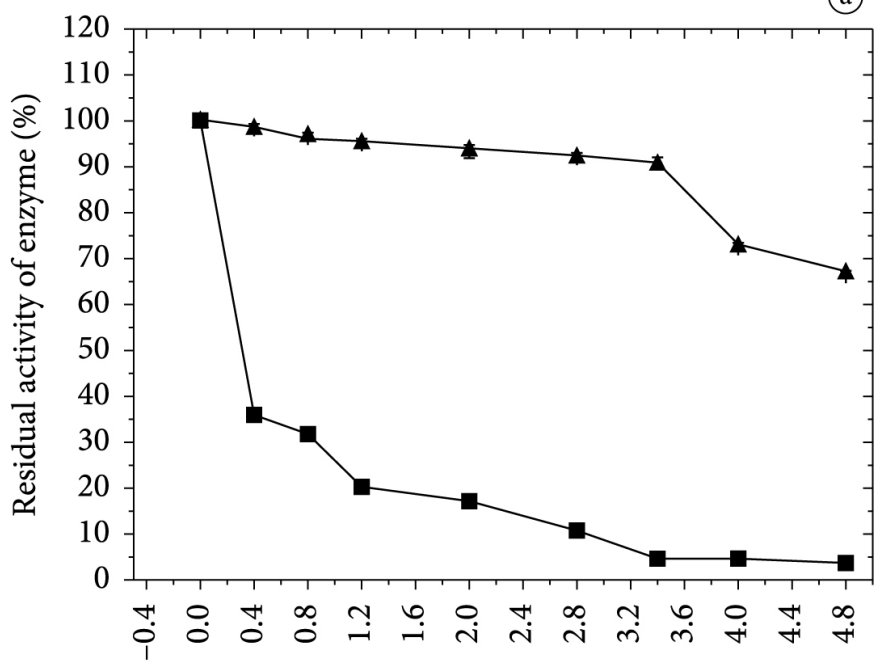

Molar ratio (inhibidor: enzyme)

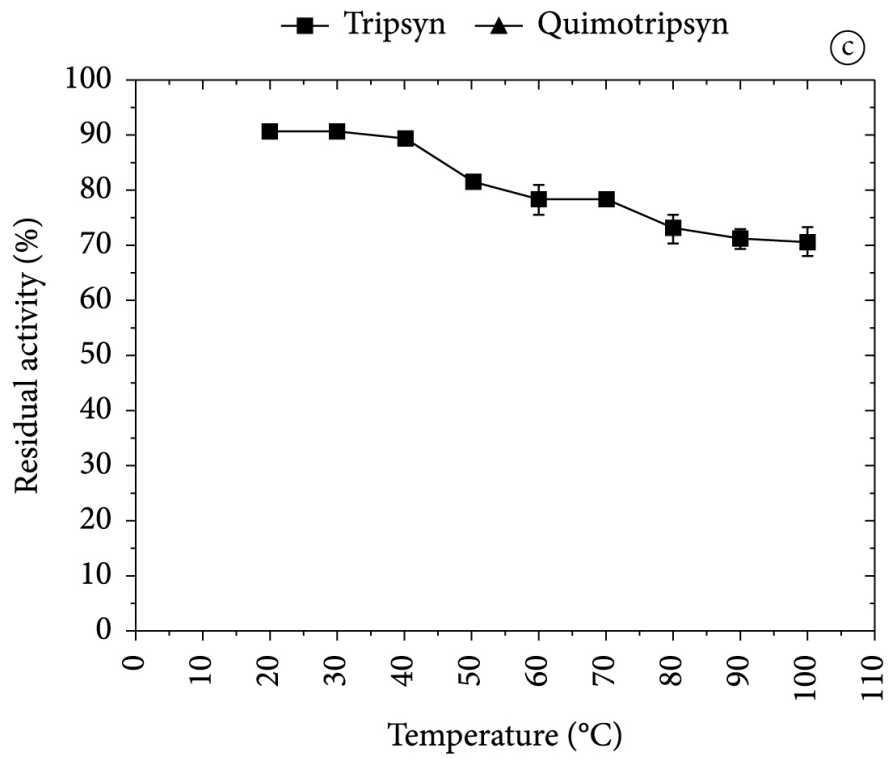

(b)

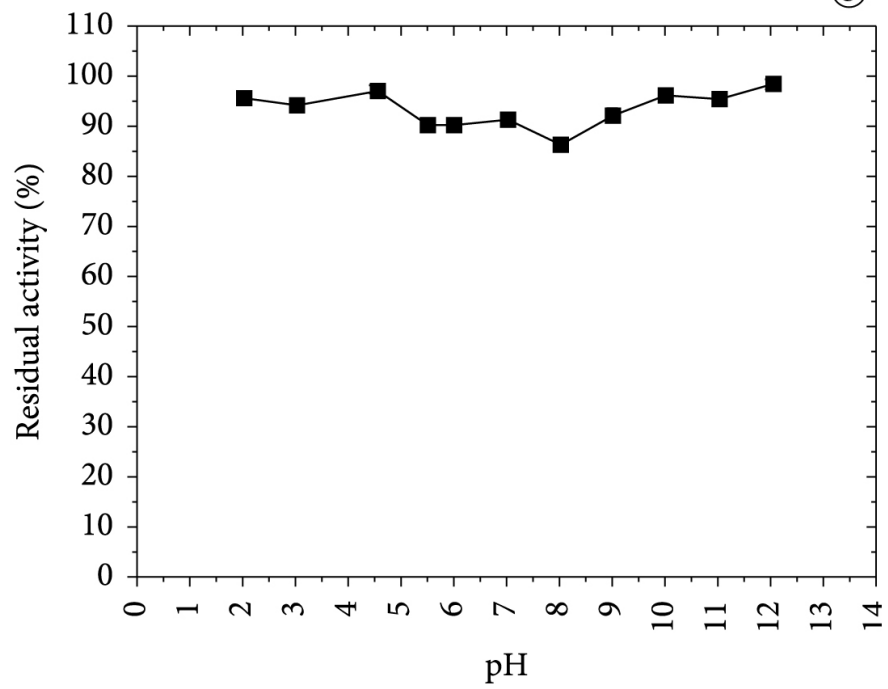

(c)

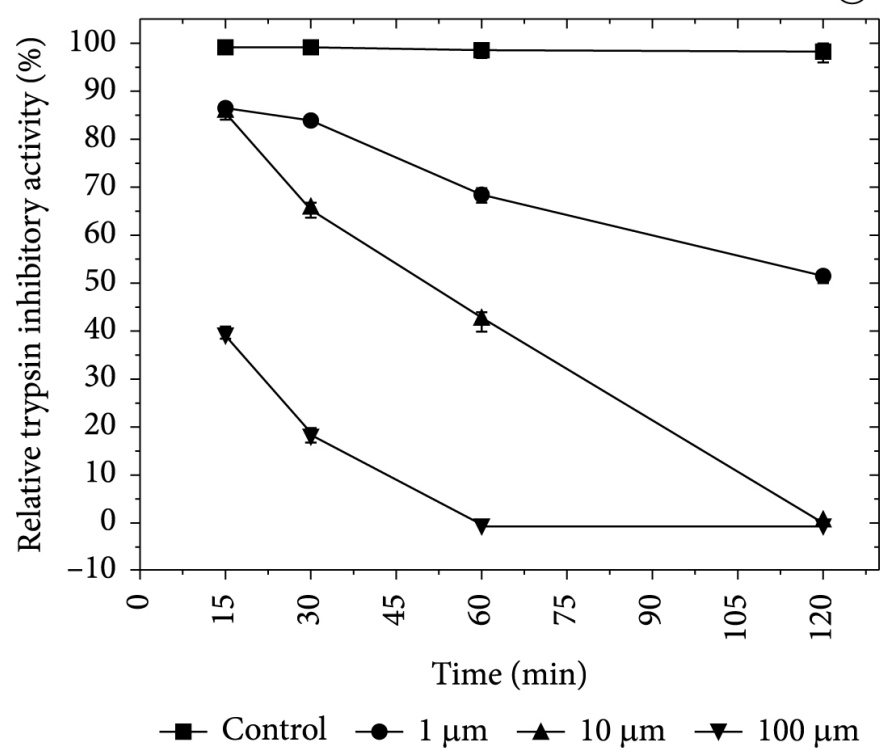

Figure 4. (a) Titration of bovine trypsin with CqTI. Enzyme concentration were $1.9 \times 10^{-7} \mathrm{M}$. After 20 min of incubation, the residual enzyme activity was measured at $37^{\circ} \mathrm{C}$ with BAPNA as substrate. Each point is the average of three assays. (b) Stability of CqTI a pH stability of SSTI, after incubation at the indicated $\mathrm{pH}$ for $1 \mathrm{~h}$ at $37^{\circ} \mathrm{C}$. (c) Temperature stability of the inhibitory activity of CqTI after incubation for 30 min at the indicated temperatures; c effect of DTT on the stability of SSTI. (d) The inhibitor was treated with different final concentrations (1, 10 and $100 \mu \mathrm{M}$ ) of DTT for $15-120 \mathrm{~min}$ at $37^{\circ} \mathrm{C}$. The residual trypsin inhibitory activity was measured using BAPNA as substrate. Values are mean \pm SD of triplicate measurements. There was significant difference between the treatments (ANOVA, $\mathrm{p}<0.05$ ). 
DTT, tryptic inhibitory activity was affected in up to $2 \mathrm{~h}(40 \%)$. When incubated with $10 \mu \mathrm{M}$ of DTT after $2 \mathrm{~h}$ the inhibitory activity was $\sim 15 \%$, proving that the influence of the reduced reagent was slow. Using $100 \mu \mathrm{M}$ of DTT, the inhibitory effect of CqTI remained $15 \%$ after $15 \mathrm{~min}$ of pre-incubation, but no activity after $1 \mathrm{~h}$ of pre-incubation was detected.

Further studies demonstrated acting of PIs on trypsin and chymotrypsin simultaneously (Xavier-Filho \& Ventura, 1998; Tamir et al., 1996; Tsybina et al., 2001; Prasad et al., 2010b). A 1:1 molar ratio with trypsin by stoichiometric studies was concorded well with other studies (Prasad et al., 2010b; Pompeu et al., 2014). The $\mathrm{pH}$ stability in large range is common in PIs. Our study is in concordance with PIs purified from cereals (Tamir et al., 1996; Tsybina et al., 2001). The temperature stability showed the same results demonstrated for SSTI from S. saponaria (Macedo et al., 2011) and RgPI from C. cajan Seeds (Prasad et al., 2010b). On the other hand, the trypsin inhibitory activity of PRTI was maintained only $20 \%$ above $80^{\circ} \mathrm{C}$ (Chaudhary et al., 2008). The effect of DTT in CqTI occured in lower levels in comparison with other studies (Prasad et al., 2010b; Macedo et al., 2011). The functional stability of PIs in the presence of various denaturants such as temperature, $\mathrm{pH}$, and reducing agents has been explained for the presence of sulfhydryl groups (Macedo et al., 2011). Moreover, PIs with tertiary structure, as dimeric, presented more stability (Macedo et al., 2011; Silva et al., 2015b).

\section{Conclusions}

The methodology to extraction and purification demonstrated three isoforms of inhibitor of protease. The amino acid composition determined high concentration of essential amino acids being similar with legume and better than other cereals. The mass spectrometry showed two subunits with molecular weight of 4.2 and 7.9KDa. It is not possible classify CqTI as the specific PI family since $\mathrm{N}$-terminal sequence of subunits found showed no homology. Its activity was stable over a $\mathrm{pH}$ (2-12), temperature $\left(20-100^{\circ} \mathrm{C}\right)$ and reducing agents.

\section{Acknowledgements}

Financial support was from the Fundação de Amparo à Pesquisa do Estado de Minas Gerais (FAPEMIG) and the Conselho Nacional de Desenvolvimento Científico e Tecnológico (CNPq). We are also grateful to P. Baldasso (UNICAMP) for his technical assistance and researcher Carlos Spehar (UnB).

\section{References}

Benjakul, S., Visessanguan, W., \& Thummaratwasik, P. (2000). Isolation and characterization of trypsin inhibitors from some Thai legume seeds. Journal of Food Biochemistry, 24(2), 107-127. http://dx.doi. org/10.1111/j.1745-4514.2000.tb00689.x.

Bhargava, A., Shukla, S., \& Ohri, D. (2006). Chenopodium quinua: an Indian perspective. Industrial Crops and Products, 23(1), 73-87. http://dx.doi.org/10.1016/j.indcrop.2005.04.002.

Bradford, M. M. (1976). A rapid and sensitive method for the quantitation of microgram quantities of protein utilizing the principle of proteindye binding. Analytical Biochemistry, 72(1-2), 248-254. http://dx.doi. org/10.1016/0003-2697(76)90527-3. PMid:942051.
Chaudhary, N. S., Shee, C., Islam, A., Ahmad, F., Yernool, D., Kumar, P., \& Sharma, A. K. (2008). Purification and characterization of a trypsin inhibitor from Putranjiva roxburghii seeds. Phytochemistry, 69(11), 2120-2126. http://dx.doi.org/10.1016/j.phytochem.2008.05.002. PMid:18561964.

Cheung, A. H., Wong, J. H., \& Ng, T. B. (2009). Trypsin-chymotrypsin inhibitors from Vigna mungo seeds. Protein and Peptide Letters, 16(3), 277-284. http://dx.doi.org/10.2174/092986609787601714. PMid:19275741.

Edman, P., Högfeldt, E., Sillén, L. G., \& Kinell, P.-O. (1950). Method form determination for amino acid sequence in peptides. Acta Chemica Scandinavica, 28, 283-293. http://dx.doi.org/10.3891/acta. chem.scand.04-0283.

Harsulkar, A. M., Giri, A. P., Patankar, A. G., Gupta, V. S., Sainani, M. N., Ranjekar, P. K., \& Deshpande, V. V. (1999). Successive use of non-host plant proteinase inhibitors required for effective inhibition of Helicoverpa armigera gut proteinases and larval growth. Plant Physiology, 121(2), 497-506. http://dx.doi.org/10.1104/pp.121.2.497. PMid:10517841.

Heinrikson, R. L., \& Meredith, S. C. (1984). Amino acid analysis by reverse-phase high-performance liquid chromatography: precolumn derivatization with phenylisothiocyanate. Analytical Biochemistry, 136(1), 65-74. http://dx.doi.org/10.1016/0003-2697(84)90307-5. PMid:6711815.

Kalume, D. E., Sousa, M. V., \& Morhy, L. (1995). Purification, characterization, sequence determination, and mass spectrometric analysis of a trypsin inhibitor from seeds of the Brazilian tree Dipteryx alata (Leguminosae). Journal of Protein Chemistry, 14(8), 685-693. http://dx.doi.org/10.1007/BF01886907. PMid:8747429.

Kim, J. Y., Park, S. C., Kim, M. H., Lim, H. T., Park, Y., \& Hahm, K. S. (2005). Antimicrobial activity studies on a trypsin-chymotrypsin protease inhibitor obtained from potato. Biochemical and Biophysical Research Communications, 330(3), 921-927. http://dx.doi.org/10.1016/j. bbrc.2005.03.057. PMid:15809084.

Klomklao, S., Benjakul, S., Kishmura, H., \& Chaijan, M. (2011). Extraction, purification and properties of trypsin inhibitor from Thai mung bean (Vigna radiata (L.) R. Wilczek). Food Chemistry, 129(4), 1348-1354. http://dx.doi.org/10.1016/j.foodchem.2011.05.029.

Klomklao, S., Benjakul, S., Kishmura, H., Osako, K., \& Tanaka, M. (2010a). Heat-stable trypsin inhibitor in adzuki bean (Vigna angularis): effect of extraction media, purification and biochemical characteristics. International Journal of Food Science \& Technology, 45(1), 163-169. http://dx.doi.org/10.1111/j.1365-2621.2009.02117.x.

Klomklao, S., Benjakul, S., Kishmura, H., Osako, K., \& Tanaka, M. A. (2010b). Effect of salts and polyethylene glycols on the partitioning and recovery of trypsin from hybrid catfish viscera in aqueous twophase systems. Journal of Food Biochemistry, 34, 730-747.

Laskowski, M. Jr, \& Kato, I. (1980). Protein inhibitors of proteinases. Annual Review of Biochemistry, 49(1), 593-626. http://dx.doi. org/10.1146/annurev.bi.49.070180.003113. PMid:6996568.

Losso, J. N. (2008). The biochemical and functional food properties of the bowman-birk inhibitor. Critical Reviews in Food Science and Nutrition, 48(1), 94-118. http://dx.doi.org/10.1080/10408390601177589. PMid:18274967.

Macedo, M. L. R., Diz, E. B. Fo, Freire, M. G., Oliva, M. L. V., Sumikawa, J. T., Toyama, M. H., \& Marangoni, S. (2011). A trypsin inhibitor from Sapindus saponaria L. seeds: purification, characterization, and activity towards pest insect digestive enzyme. The Protein Journal, 30(1), 9-19. http://dx.doi.org/10.1007/s10930-010-9296-7. PMid:21127952. 
Macedo, M. L. R., Garcia, V. A., Freire, M., \& Richardson, M. (2007). Characterization of a Kunitz trypsin inhibitor with a single disulfide bridge from seeds of Inga laurina (SW.) Willd. Phytochemistry, 68(8), 1104-1111. http://dx.doi.org/10.1016/j.phytochem.2007.01.024. PMid:17363015.

Machado, R. J. A., Monteiro, N. K. V., Migliolo, L., Silva, O. N., Pinto, M. F. S., Oliveira, A. S., Franco, O. L., Kiyota, S., Bemquerer, M. P., Uchoa, A. F., Morais, A. H. A., \& Santos, E. A. (2013). Characterization and pharmacological properties of a novel multifunctional Kunitz inhibitor from Erythrina velutina seeds. PLoS One, 8(5), 1-14. http:// dx.doi.org/10.1371/journal.pone.0063571. PMid:23737945.

Nakahata, A. M., Mayer, B., Ries, C., de Paula, C. A., Karow, M., Neth, P., Sampaio, M. U., Jochum, M., \& Oliva, M. L. V. (2011). The effects of a plant proteinase inhibitor from Enterolobium contortisiliquum on human tumor cell lines. Biological Chemistry, 392(4), 327-336. http://dx.doi.org/10.1515/bc.2011.031. PMid:21781023.

Park, S. S., Abe, K., Kimura, M., Urisu, A., \& Yamasaki, N. (1997). Primary structure and allergenic activity of trypsin inhibitors from the seeds of buckwheat (Fagopyrum esculentum Moench). FEBS Letters, 400(1), 103-107. http://dx.doi.org/10.1016/S00145793(96)01367-1. PMid:9000522.

Pompeu, D. G., Carvalho, A. S., Costa, O. F., Galdino, A. S., Bonoto, D. G., Silva, J. A., \& Granjeiro, P. A. (2014). Anti-nutritional factors and in vitro digestibility of leaves of Pereskia aculeata Miller. Biochemistry and Biotecnology Reports, 1, 1-9. http://dx.doi.org/10.5433/2316$5200.2014 \mathrm{v} 3 \mathrm{n} 1 \mathrm{p} 1$.

Prasad, E. R., Dutta-Gupta, A., \& Padmasree, K. (2009). Inhibitors from pigeonpea active against lepidopteran gut proteinases. Journal of Economic Entomology, 102(6), 2343-2349. http://dx.doi. org/10.1603/029.102.0641. PMid:20069866.

Prasad, E. R., Dutta-Gupta, A., \& Padmasree, K. (2010a). Purification and characterization of a Bowman-Birk proteinase inhibitor from the seeds of black gram (Vigna mungo). Phytochemistry, 71(4), 363-372. http://dx.doi.org/10.1016/j.phytochem.2009.11.006. PMid:20018332.

Prasad, E. R., Merzendorfer, H., Madhurarekha, C., Dutta-Gupta, A., \& Padmasree, K. (2010b). Bowman-Birk proteinase inhibitor from Cajanus cajan seeds: purification, characterization, and insecticidal properties. Journal of Agricultural and Food Chemistry, 58(5), 28382847. http://dx.doi.org/10.1021/jf903675d. PMid:20146519.

Rai, S., Aggarwal, K. K., Mitra, B., Das, T. K., \& Babu, C. R. (2010). Purification, characterization and immunolocalization of a novel protease inhibitor from hemolymph of tasar silkworm, Antheraea mylitta. Peptides, 31(3), 474-481. http://dx.doi.org/10.1016/j. peptides.2009.08.021. PMid:19723549.

Rao, K. N., \& Suresh, C. G. (2007). Bowman-Birk protease inhibitor from the seeds of Vigna unguiculata forms a highly stable dimeric structure. Biochimica et Biophysica Acta, 1774(10), 1264-1273. http://dx.doi.org/10.1016/j.bbapap.2007.07.009. PMid:17869196.

Rocco, M., Malorni, L., Chambery, A., Poerio, E., Parente, A., \& Di Maro, A. (2011). A Bowman-Birk inhibitor with anti-elastase activity from Lathyrus sativus L. seeds. Molecular BioSystems, 7(8), 2500-2507. http://dx.doi.org/10.1039/c1mb05141e. PMid:21647515.

Ruales, J., \& Nair, B. M. (1992). Nutritional quality of the protein in quinoa (Chenopodium quinoa, Willd) seeds. Plant Foods for Human Nutrition (Dordrecht, Netherlands), 42(1), 1-11. http://dx.doi. org/10.1007/BF02196067. PMid:1546052.
Ruan, J. J., Chen, H., Shao, J. R., Wu, Q., \& Han, X. Y. (2011). An antifungal peptide from Fagopyrum tataricum seeds. Peptides, 32(6), 1151-1158. http://dx.doi.org/10.1016/j.peptides.2011.03.015. PMid:21453738.

Schägger, H., \& von Jagow, G. (1987). Tricine-sodium dodecyl sulfatepolyacrylamide gel electrophoresis for the separation of proteins in the range from 1 to $100 \mathrm{kDa}$. Analytical Biochemistry, 166(2), 368-379. http://dx.doi.org/10.1016/0003-2697(87)90587-2. PMid:2449095.

Silva, J. A., Macedo, M. L. R., Novello, J. C., \& Marangoni, S. (2001). Biochemical characterization and $\mathrm{N}$-terminal sequences of two new trypsin inhibitors from Copaifera langsdorffi seeds. Journal of Protein Chemistry, 20(1), 1-7. http://dx.doi.org/10.1023/A:1011053002001. PMid:11330343.

Silva, J. A., Pompeu, D. G., Costa, O. F., Gonçalves, D. B., Spehar, C. R., Marangoni, S., \& Granjeiro, P. A. (2015a). The importance of heat against antinutritional factors from Chenopodium quinoa. Food Science and Technology (Campinas), 35(1), 74-82. http://dx.doi. org/10.1590/1678-457X.6427.

Silva, J. A., Pompeu, D. G., Smolka, M. B., Gozzo, F. C., Comar, M., Eberlin, M. N., Granjeiro, P. A., \& Marangoni, S. (2015b). Primary structure of a trypsin inhibitor (CTI-1) obtained from Copaifera langsdorffi seeds: a Kunitz trypsin-type inhibitor with two subunits and a single disulfide bridge. Journal of Biomolecular Techniques, 26(3), 90-102. http://dx.doi.org/10.7171/jbt.15-2603-002.

Spehar, C. R., \& Santos, R. L. B. (2002). Quinoa BRS Piabiru: alternativa para diversificar os sistemas de produção de grãos. Pesquisa Agropecuaria Brasileira, 37(6), 889-893. http://dx.doi.org/10.1590/ S0100-204X2002000600020.

Stikic, R., Glamoclija, D., Demin, M., Vucelic-Radovic, B., Jovanovic, Z., Milojkovic-Opsenica, D., Jacobsen, S., \& Milovanovic, M. (2012). Agronomical and nutritional evaluation of quinoa seeds (Chenopodium quinoa Willd.) as an ingredient in bread formulations. Journal of Cereal Science, 55(2), 132-138. http://dx.doi.org/10.1016/j. jcs.2011.10.010.

Tamir, S., Bell, J., Finlay, T. H., Sakal, E., Smirnoff, P., Gaur, S., \& Birk, Y. (1996). Isolation, characterization, and properties of a trypsinchymotrypsin inhibitor from amaranth seeds. Journal of Protein Chemistry, 15(2), 219-229. http://dx.doi.org/10.1007/BF01887402. PMid:8924206.

Tsybina, T. A., Dunaevsky, Y. E., Musolyamov, A. K., Egorov, T. A., \& Belozersky, M. A. (2001). Cationic inhibitors of serine proteinases from buckwheat seeds. Biochemistry, 66(9), 941-947. http://dx.doi. org/10.1023/A:1012388805336. PMid:11703172.

Vega-Gálvez, A., Miranda, M., Vergara, J., Uribe, E., Puente, L., \& Martínez, E. A. (2010). Nutrition facts and functional potential of quinoa (Chenopodium quinoa willd.), an ancient Andean grain: a review. Journal of the Science of Food and Agriculture, 90(15), 2541-2547. http://dx.doi.org/10.1002/jsfa.4158. PMid:20814881.

Xavier-Filho, J., \& Ventura, M. Z. M. (1998). Trypsin inhibitors in Cowpea: a review. Comments on Agricultural and Food Chemistry, $1,239-264$.

Zhang, Y., Zhou, C., Tang, S., Yu, X., Kouzuma, Y., \& Yonekura, M. (2011). Effect of AATI, a Bowman-Birk type inhibitor from Apios americana, on proliferation of cancer cell lines. Food Chemistry, 128(4), 909-915. http://dx.doi.org/10.1016/j.foodchem.2011.03.117. 